\title{
The Changing Shopping Culture: Internet Consumer Behavior
}

\author{
Elif Eroğlu, Anadolu University, Turkey
}

\begin{abstract}
Internet technology has prompted significant changes in many aspects of human life and society as well as in shopping culture. An important phenomenon, surrounding the human life as a continuum, is shopping through the Internet or e-commerce. Shopping through the Internet has interconnections with many disciplines such as law, economics, psychology, and marketing. Many academicians, researching in various disciplines, studied this issue, which is a dynamic field of study. However, the case is this, we can say that the studies about the reasons for shopping through Internet by the consumers are very new and few in number. Shopping through the Internet involves social, technological, economical, behavioral, and educational dimensions. There are many prior factors behind shopping through the Internet by the consumers. This study presents a theoretical explanation for online consumer behavior.
\end{abstract}

Keywords: Online Shopping; Consumer Behavior; Internet Shopping; Technology Acceptance Model

\section{INTRODUCTION}

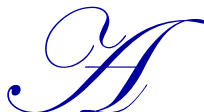

ccording to Nielsen (2012) research, one-third of the world's population is online, an increase of $528 \%$ over the past 10 years. While Internet penetration rates vary by geographic region; North America (79\%), Australia/Oceania (68\%), Europe (61\%), Latin America (40\%), Middle East (36\%), Asia $(26 \%)$, and Africa (14\%), these rates continue to climb steadily. The Internet is the primary source for information research and has significantly affected the dynamics of business, both in terms of innovation and increased sales. The U.S. Census Bureau e-stats Report released May 27, 2010, revealed that U.S. retail e-commerce sales were $\$ 142$ billion in 2008, a gain of 3.3\% from the previous year. For the first three quarters of 2011, U.S. retail e-commerce sales amounted to $\$ 135.9$ billion. Marketers and researchers have examined the behavior of online consumers. In particular, how do demographics and psychographics play a part the pre-purchase information search? (Zayer \& Coleman, 2012) Connected devices, such as computers, mobile phones, and tablets have become a way of life for many. But customers are digitally engaged to varying degrees, depending on the products they buy. It is important to understand the behavior of consumers toward online shopping. Therefore, online shopping environments are playing an increasing role in the relationship between marketers and their consumers (Hsieh \& Liao, 2011).

\section{IMPORTANCE OF ONLINE SHOPPING}

Driven by technology and evolving consumer demand, the shopping experience has been transformed. With the variety of shopping-enhancement options currently available, the consumer experience is gradually shifting from being product-centric to consumer-centric. The integration of the Internet and mobile data with "brick and mortar" is critical to obtain a more complete view of the consumer. The paradigm shift in consumer behavior has increased the need to effectively connect with consumers. Advances in technology and the emergence of digital media are bringing a new wave of consumerism. For many consumers, a shopping trip includes relaxation, a source of entertainment or a chance to socialize and share experiences. Consumers are progressively seeking shopping options that offer increased convenience and flexibility. Firms are responding to these evolving consumer needs through the introduction of relevant innovative solutions and the integration of online experiences (KPMG, 2012). Today online consumers have more control and bargaining power than consumers of physical stores. The Internet offers more interactivities between consumers and product/service providers as well as greater availability of 
information about products and services. Geissler and Zinkhan (1998) claimed that the Internet shifted the balance of power in favor of consumers as it became very easy for them to make shopping comparisons and evaluate alternatives without being pressured by salespeople. Online stores reduce transaction costs and have advantage for both consumers and vendors (Javadi \& Others, 2012).

According to the results obtained from the online shopping survey conducted through PWC (2013) in 11 countries with more than 13 thousand consumers, one of the reasons that makes shopping at traditional stores attractive for consumers is the fact of being able to see the products as well as touching and trying them. Furthermore, the possibility of obtaining the purchased products immediately also plays an important role as to the cited issue; however, online stores are trying to reduce their disadvantages with options such as fast delivery and free product returns. Consumers in Turkey, France, and the UK state that the reasons they prefer shopping on the Internet is generally to find information on online campaigns. Swiss consumers express that the main reason for their shopping on the Internet is the convenience with the addition to home delivery of the products. According to the survey, most of the participant's state that they are doing shopping on the Internet as is easier than going to a store. Much as the research reveals that most of the consumers make more spending on the points of sale they like when they use multiple shopping channels, it refutes the traditional idea that sales in stores will decrease due to shopping on the Internet. It can be seen here that businesses should use both online and traditional channels together in our day (http://dunya.com).

\section{THEORETICAL BACKGROUND FOR ONLINE CONSUMER BEHAVIOR}

Internet shopping action has theoretically been studied based on the axis of the theories relating to "innovation adopting." It can be thought that shopping through the Internet is post-learned and therefore an innovation. What variables play roles for the consumers in adopting this innovation? Based on the axis of willingness or unwillingness for shopping through Internet, the aim of this study is to reveal the reasons of the differences observed among the consumers in terms of willingness for shopping. This is a review examining Internet usage, and more specifically shopping behavior highlighting consumers' motivations and behaviors. There is neither a theory that fully explains the reasons why consumers shop on the Internet nor a common ground the researchers can agree. Why do consumers prefer online shopping to traditional shopping? Why do some individuals utilize online shopping more than others? Is there a difference between those who make online shopping intensively and those who make traditional shopping? Which factors are important in consumers' decisions to shop online? The difficulty of not being able to explain the online consumer behavior by a single theory can be better understood considering these questions in general. There are various approaches germane to dealing with this issue and cited approaches often bear the nature of complementing each other.

Socio-psychological approaches become prominent in description of the behaviors of online consumers. Socio-psychological theories are based on the studies carried out by Fishbein (1963) and Fishbein and Ajzen (1975). Technology, innovation, and adopting or not adopting of the new products is considered to be a behavior in the foregoing approaches. In this context, a behavior is a person's observable action towards an intention or purpose performed in an environment where prior conditions are constant. An important assumption employed in these theories is that the individuals are rational. The rational individual takes into consideration many factors in terms of adopting. When other factors are constant, the rational individual focuses on benefits and costs of each factor and in case a benefit concerning an innovation outweighs the costs of such an innovation than the individual adopts that innovation. The benefits and costs specified in these approaches are not limited to the monetary dimensions. Numerous human feelings and benefits such as feeling good about oneself, the ego, entertainment, social acceptance, and frustration are the components of cost accounting. In this study, Extended Technology Acceptance Model (ETAM), an improved version of Technology Acceptance Model (TAM) which is a socio-psychological theory to explain the behavior of the online consumer, is discussed theoretically.

\section{Evaluation of Consumer Behavior on the Internet through the Extended Technology Acceptance Model}

TAM was developed by Davis (1989) to determine in particular the factors that influence individuals' acceptance of new technologies and is based on Theory of Reasoned Action (TRA). TRA is a socio-psychological based theory of behavior developed through Fishbein and Ajzen (1975). This theory is rooted from the multi- 
attribute attitude theory developed through Fishbein (1963). Fishbein's (1963) theory reveals that a person's attitude towards an object or innovation is based on the belief and evaluation that the person has with respect to a cited object or innovation (Sendecka, 2006). The adoption of a new product or an innovation is a behavior made by an individual. In the journey to the emerging behavior or realized behavior (adoption of a new product), the person's decision on the new product comes up as a result of an interaction of several psychology based variables. According to this theory, social behavior of a human is under the control of certain factors. The main point to be studied in the analysis of the question of what could be of the behavior of a person in the adoption of an action or an innovation should be bringing forward "Intention towards Behavior" of that person. The intention towards behavior is the degree of effort achieved through a person to demonstrate a certain behavior. The willingness of the person for the elimination of these difficulties should be as strong as the intention thereby in adopting this innovation. The possibility of the occurrence of the behavior in question will be larger in parallel with the strength of the intention towards behavior (Erten, 2002). In essence intention towards behavior depends on two main variables. The first is "Behavioral Intention (BI)" and the second is "Subjective Norm." BI is the positive or negative emotions that a person has related to the target behavior (Fishbein \& Ajzen, 1975). The thing which is more important than the decision for adopting or not adopting an innovation is the attitude the person has for this innovation. If a person has a negative attitude or idea towards online shopping, it would be wrong to expect that person to place orders online. A person's behavior is not independent from the thoughts of other people. People are influenced through the opinions of people around them to whom they give value. How the person will be affected through the ideas of the people around him in the decision-making process is defined as the "Subjective/Personal Norm." Subjective norm denotes the case that a person is in the expectation of observing whether persons who are important for him (reference persons) or institutions and organizations that are important for the person will realize or abandon a certain behavior (Erten, 2002). These norms constitute the person's perception what people around him will think if he behaves in a certain way. "Subjective Norms" are the social factors or social thoughts that are possible to have an impact on the behavior of the person. The rational individual may act contrary to the reference persons although he remains under the influence of the ideas of the people around him. The individual will be able to calculate the benefits and losses arising from this contrary action. Motivation briefly can be considered as the calculation of individual profit and loss. A person's intention towards behavior will be as strong in line with the strength of the motivation (Venkates \& Davis, 2000).

Theory of Planned Behavior (TPB) is a study by Ajzen (1991). This approach was established by developing the Theory of Reasoned Action (TRA) of Fishbein and Ajzen (1975) and included the concept of perceived behavioral control. Perceived behavior control denotes the belief that a person can or cannot achieve the said behavior and how easy or how difficult it would be for him to perform the cited behavior (Sendecka, 2006). According to another definition, perceived behavior control denotes all of the internal and external barriers to perform a behavior (Taylor \& Todd, 1995). The main difference between this theory and TRA is the perceived behavioral control variable. This variable emerges as another factor determining "Intention towards Behavior." The purpose of adding this variable is that in some cases individuals do not have sufficient ability to fully control their behaviors. To make a behavior on one hand is associated with the possibilities and opportunities that a person has it also depends on a number of resources such as money, time, talent, and the ability to receive assistance (Harrison et al., 1997). For this reason, in addition to attitudes and personal norms, the person can make a specific behavior when he has resources such as money, time, and skills. The essence of this approach is that the behavior ability of human behavior is associated with the resources he has. The difficulty degree of behavior is perceptual for the person and ability to increase or decrease the degree of difficulty is called "Perceived Behavior Control." There are two components of "Perceived Behavior Control." The first of these components is "Control Belief" and can be defined as the power to be able of controlling to reduce or increase the degree of difficulty in performance of the behavior by a person on the basis of the experience acquired in the past or basing on secondary information. "Perceived Power" can be described as how sufficient the person feels himself incident to achievement of a behavior (Sendecka, 2006).

TAM has been used for a long time to learn the attitudes and behaviors of employees on new technologies in workplaces (TUIK, 2006). Popularization of online shopping has led many researchers to research the basis of this issue. In these studies, this theory was employed while the answer to the question of "how online shopping gained prevalence" was searched. This theory has also been adapted to the topic regarding how many products have gained prevalence in the society (Pagani, 2004). Studies have revealed that TAM can explain "Intention towards Behavior" and therefore "behavior" could be by more than $40 \%$ of the changes occurring in "behavior." Therefore it 
can be said that TAM has proven to be more successful than both the Theory of Reasoned Action and the Theory of Planned Behavior (Sendecka, 2006).

TAM is based on the idea that the attitude of a person in using a system (hardware, software, innovation, etc.) is determined by two main factors as "Perceived Ease of Use (PEU)" and the "Perceived Usefulness (PU)" (Aykaç et al., 2007). PU indicates the belief that the use of a particular system (hardware, software, innovation, etc.) will make changes in the performance. PU relates to the performance increase provided to a user in utilization of any technology, performing specific tasks, and solving issues. PEU denotes a person's belief that use of a particular system does not require much effort (Davis, 1989). Attitudes of a person to an innovation or a new technological product which they consider to adopt will be more positive depending on how easy is the use of such a product. Both PU and PEU influence consumer online shopping intentions. Although online shopping has been assumed to have beneficial outcomes, using an interactive website could prove to be discouraging for some consumers. If this negative perception of the process outweighs the perceived benefits of purchasing using the Internet (e.g., long download times, poorly designed formatting), then potential Internet shoppers are likely to continue purchasing using conventional channels. In other words, if there are barriers that reduce perceptions of ease of use of Internet shopping, Internet users may develop a negative attitude toward Internet shopping (Hsieh \& Liao, 2011).

TAM has been developed by the studies of Venkates and Davis (2000). This theory is referred to as the "Extended Technology Acceptance Model (ETAM)." Behavior of adopting online purchasing can be affected by social and environmental factors in a significant manner. ETAM has been created to explain in full the social influence made to "Attitudes towards Behavior" variable by adding the "Subjective Norm" variable to TAM. In other words, in addition to the "Perceived Ease of Use" and "Perceived Behavioral Control" variables "Subjective Norm-SN" variable also determines the behavior of the consumers shopping online (Venkates \& Davis, 2000). ETAM, discussed with the basis and the development together hereinabove, is proposed as a new model to explain the behavior and intention of consumers' incident to online shopping and its adequacy is measured. This study hereby constitutes the first step of an empirical study to be performed later and has been carried out with an eye to determine the prediction power of ETAM consumer in terms of online shopping behavior and intentions.

\section{CONCLUSION}

The Internet has a significant impact on every aspect of life including shopping habits. Shopping on the Internet, due to its being a synthesis of marketing practices and technology management principles has become an issue gaining importance for marketers and academics. Internet eliminates geographical limitations and ensures users have more information with much less time and cost. Furthermore, it provides both enterprises and consumers with products and services according to their personal desires, needs, and demands and gives them the opportunity of delivery within much less time and lower cost. In this context, it is important for the companies to understand the behavior of consumers making purchases on the Internet and develop appropriate strategies accordingly.

Theories explaining traditional consumer behaviors are inadequate to describe online consumer behaviors. It is important to carry out theoretical and empirical studies moving forward. It has been revealed that there are many factors that have an effect on online consumer behaviors; however, a research model has not been developed to cover all potential factors. Studies conducted have focused on various factors. For example, Koufaris (2002) conducted a study of information systems (Technology Acceptance Model), marketing (consumer behavior), and psychological factors. Pavlou (2003) investigated the relationship between of consumer acceptance with confidence in e-commerce, perceived risk, usability, and usefulness. Pavlou and Fygenson (2006) have tried to explain the adaptation of consumers to electronic commerce by expanding the theory of planned behavior (Ajzen, 1991). These researches must be carried out by different aspects and should be made in relation to other sciences, such as, psychology. In the Ajzen article, Extended Technology Acceptance Model (ETAM), one of the socio-psychological theories, provide researchers and practitioners with important information as to explaining the basics of consumer behavior related to online shopping and furnishes a theoretical background which will be important for empirical studies to be carried out. 


\section{NOTE}

This study was presented as a Poster at "The Clute Institute International Academic Conference in Breckenridge" on 05-07 August 2013, in Breckenridge, Colorado (USA), and was reviewed and extended into an article.

\section{AUTHOR INFORMATION}

Elif Eroğlu, Ph.D., is an Assistant Professor of the Marketing Department at Anadolu University, Turkey. She is currently on scholar study at University of Nevada-Reno. Her areas of research include consumer behavior, marketing management, and technological product purchasing. She has published several book chapters and editors such as marketing management and technological product retailing. Also, she has numerous articles in academic journals. E-mail: eleroglu@ anadolu.edu.tr

\section{REFERENCES}

1. Ajzen, I. (1991). Theory of planned behavior. Organizational Behavior and Human Decision Processes, 50 (2), 179-211.

2. Ajzen, I., \& Fishbein. M. (1980). Understanding attitudes and predicting social behavior. Englewood Cliffs, New Jersey: Prentice-Hall.

3. Aykaç, D. S. Ö., Eryarsoy, E., Kasap N., \& Kervenoael, R. (2007). Türkiye'de E-Devlet Hizmetleri İçin Mobil Telefonlarin Kullanımı. Retrieved 03/04/2013 from http://people.sabanciuniv.edu/nihatk/NihatKasap_BEYKON2007.pdf

4. Chen, L. (2009). Online consumer behavior: An empirical study based on theory of planned behavior. (Doctor of Philosophy) The Graduate College at the University of Nebraska.

5. Darley, W. K., Blankson, C., \& Luethge, D. J. (2010). Consumer behavior and decision making process: A review. Psychology and Marketing, 27(2), 94-116.

6. Davis, F. D. (1989). Perceived usefulness, perceived ease of use and user acceptance of information technology. Management Information System Quarterly, 13(3), 319-340.

7. Erten, S. (2002). Planlanmıs Davranış Teorisi İle Uygulamalı Ders İşleme Ögretim Metodu. Hacettepe Üniversitesi Edebiyat Fakültesi Dergisi, 19(2), 217-233.

8. Fishbein, M., \& Ajzen, I. (1975). Belief, attitude, intention, and behavior: An introduction to theory and research. Boston, MA: Addison-Wesley.

9. Harrison, D. A., Mykytyn, P. P., \& Riemenschneider, C. K., (1997). Executive decisions about adoption of information technology in small business: Theory and empirical tests. Information Systems Research, 8(2).

10. Hsieh, J. Y., \& Liao, P. W. (2011). Antecedents and moderators of online shopping behavior in undergraduate students. Social Behavior and Personality, 39(9), 1271-1280.

11. Huang, P., \& Sycara, K. (2002). A computational model for online agent. Negotiation. System Sciences Proceedings of the 35th Hawaii International Conference, Hawaii.

12. Huang, S., \& Lin, F. (2007). The design and evaluation of an intelligent sales agent for online persuasion and negotiation. Electronic Commerce Research and Applications, 6(3), 285-296.

13. Javadi, M. H. M., Dolatabadi, H. R., Nourbakhsh, M., Poursaeedi, A., \& Asadollahi, A. R. (2012). An analysis of factors affecting on online shopping behavior of consumers. International Journal of Marketing Studies, 4(5), 81-98.

14. Keller, C. (2005). Virtual learning environments: Three implementation perspectives. Learning, Media and Technology, 30(3), 299-311.

15. Keisidou, E., Sarigiannidis, L., \& Maditinos, D. (2011). Consumer characteristics and their effect on accepting online shopping, in the context of different product types. International. Journal of Business Science and Applied Management, 6(2), 31-51.

16. Koufaris, M. (2002). Applying the technology acceptance model and flow theory to online consumer behavior. Information Systems Research, 13(2), 205-223.

17. KPMG International, (2012). Issues monitor sharing knowledge on topical issues in the retail industry, September, 12. Retrieved 05/06/2013 from www.kpmg.com 
18. Kwek, C. L., Tan, H. P., \& Lau T. C. (2010). Investigating the shopping orientations on online purchase intention in the e-commerce environment: A Malaysian study. Journal of Internet Banking and Commerce, 15(2), 1-22.

19. Nielsen, (2012). How digital influences how we shop around the world. Retrieved 04/07/2013 from http://fi.nielsen.com/site/documents/NielsenGlobalDigitalShoppingReportAugust2012.pdf

20. Pagani, M., (2004). Determinants of adoption of third generation mobile multimedia services. Journal of Interactive Marketing, 18(3), 46-59.

21. Pavlou, P. A., \& Fygenson, M. (2006). Understanding and predicting electronic commerce adoption: An extension of the theory of planned behavior. MIS Quarterly, 30(1), 115-143.

22. Sendecka, L. (2006). Adoption of mobile services moderating effects of service's information intensity. Norges Handelshøyskole (Master Thesis). Thesis in Markedsføring og Konkurranse, Norway.

23. Su, D., \& Huang, X. (2011). Research on online shopping intention of undergraduate consumer in China-Based on the theory of planned behavior. International Business Research, 4(1), 86-92.

24. Taylor, S., \& Todd, P. A. (1995). Understanding information technology usage a test of competing models. Information Systems Research, 6(2), 144-176.

25. TUIK (2006). Girişimlerde Bilişim Teknolojileri Kullanımı Araştırması. T.C. Başbakanlık Türkiye İstatistik Kurumu Haber Bülteni: Türkiye İstatistik Kurumu, 1(2).

26. Venkatesh, V., \& Davis, F. D. (2000). A theoretical extension of the technology acceptance model: four longitudinal field studies. Management Science, 46(2), 186-204.

27. Vijaysarathi, L., \& Jones, J. M. (2000). Intentions to shop using internet catalogues: Exploring the effects of product types, shopping orientations, and attitudes towards computers. Electronic Markets, 10(1), 29-38.

28. Yu, T., \& Wu, G. (2007). Determinants of internet shopping behavior: An application of reasoned behavior theory. International Journal of Management, 24(4), 744-762.

29. Zayer, L. T., \& Coleman, P. (2012). Male consumers' motivations for online information search and shopping behavior. In A. G. Close (ed.), Online consumer behavior: Theory and research in social media, advertising and e-tail. Hoboken: Routledge Academic.

30. _ Online alışveriş yapanların gizemi. Retrieved 09/03/2013 from http://dunya.com/onlinealisveris-yapanlarin-gizemi 